\title{
European, national or global? Elite schools in post- communist Poland
}

\author{
ALEXANDRA DUNWILL
}

alexandradunwill@mac.com

\begin{abstract}
Competing socio-historical forces are now impacting on school education in Poland in ways that were not possible under the communist system, but have emerged since 1989 under the influence of different elite groups. The result is the emergence of different types of schooling for different groups of elites and of categories of elite schools representing varying degrees of convergence of European and national identity. This article focuses on these changes to the education system between 1989 and 2018 , highlighting the influences of socio-political factors that facilitated the emergence of elite schools with diverse missions and outlooks.
\end{abstract}

Keywords: Education; Elites; Poland; Elite schools in Poland; Educational transformation in Poland; Elite education market; Socio-political outlooks of elites; Commercialisation of education

\section{Introduction ${ }^{1}$}

The political and economic changes that occurred in Poland in 1989 and the early 1990 allowed for a significant restructuring of the education system and created a platform for the emergence of new, non-public schools that were not bound by the rules of the previously existing government controlled and centralised system of education. New schools could be created by legal and natural entities and the new legal arrangements allowed for partnerships between Polish and foreign citizens to enter the education market. As a result, a number of Polish-international partnerships, as well as foreign entities, opened new educational enterprises in Poland. It was also an opportunity for parents, teachers and community groups to set up independent schools that better reflected their ideals and beliefs. While this process has provided a school choice for parents in Poland it has also resulted in a significant reconfiguration of the education 'market' with different levels of prestige. Education in Poland is predominantly government funded and prestige was traditionally associated with topranking government schools with long histories and traditions. However, the elite school market has been growing rapidly and wealthy parents are increasingly seeking education in the non-government sector.

\footnotetext{
${ }^{1}$ This paper draws on my PhD study conducted under the supervision of Professor Jane Kenway and Dr Howard Prosser at the Monash University. The study is a part of Australian Research Council funded project, Elite independent schools in globalizing circumstances: a multi-sited global ethnography, www.monash.edu.au/education/research/projects/category-1/arc-decra/eliteindependent-schools-in-globalisingcircumstances, under the leadership of Professor Jane Kenway.
} 
Although there is a degree of exclusivity associated with non-public schools that charge fees, only a few non-government schools are considered elite. Similarly, in a government sector that currently caters to a majority of students, only a few have developed a prestigious reputation. This article focuses on the changes to the education system between 1989 and 2018, highlighting the influences of socio-political factors that facilitated the emergence of elite schools with diverse missions and outlooks. Furthermore, the paper illuminates the social transformations that have taken place in Poland and how they were facilitated by the changing education 'market'.

\section{Theory and method}

The definition of what constitutes an elite school in Poland is challenging. Elite status is usually a correlation of two factors: excellent measurable results and high stratification potential that is usually linked to a school's prestige and alumni network (Kenway \& Koh, 2015). Public perception, however, particularly among elite groups, is also an important factor (Bowman \& Bastedo, 2009). According to Vidaver-Cohen (2007), a good reputation is considered to be one of the non-material assets that an organisation may possess. No doubt, different secondary schools have different reputations but elite schools have the best reputation among elite groups. GaztambideFernández (2009) suggests elite schools' prestige comes from their ability to be exclusive and excluding as they have control over the selection processes. In Poland, the perception of a school's prestige among the general public and the school's alumni, students, parents and teachers is a contributing factor to the school's status as elite.

While conducting a preliminary research, it became clear to me that the most prestigious education institutions in Poland are not homogenous and that the differences between various types are too big to ignore. In contrast, it was easy to notice, even in the early stages of my research, that the elite schools differ according to the characteristics and outlooks of the elites that create, select and support them.

To facilitate a better understanding of the diversity of elite schools' socio-political outlooks in Poland, I developed a conceptual framework consisting of four critical perspectives, that I call 'four angles of scrutiny'. My theory/conceptual framework elucidates the constellation of forces that have been buffeting Poland historically before and after the 1989 Solidarity revolution. The dominant forces, which have attendant implications for elite formation and elite school education, generally fit into four broad categories: globalisation, European integration, socialist heritage and tradition. These forces are sometimes reinforced and sometimes hindered by the ideological predispositions of different elite groups. Each angle of interpretation helps to explain a major feature of the multidimensional and fundamental changes that have occurred during the last thirty years of post-communist transformation.

To establish the unique characteristics of Polish elite schools required a mix of different methods which are only briefly described in this article. The data is drawn from multiple sources and involves elicited (generated) and extant (selected) data sets such as in-depth, semi-structured interviews of 1-1.5-hour duration with principals or deputy principals from selected elite schools, elite schools' websites and online media commentaries, with the texts illuminating public discourse by contributing a range of views and experiences. Consequently, I focused on a small group of most prestigious schools in Warsaw, on which to conduct my research. These schools are all considered elite yet show significant differences in their missions and socio-political outlooks. 
I will now briefly introduce the four critical perspectives (four angles of scrutiny) that form the analytical framework of this study and illustrate some of the arising insights each offers. It should be noted that, for the purpose of analysis, I separate these perspectives while, of course, in reality they frequently overlap and merge.

\subsection{Globalisation}

Academic literature commonly subdivides globalisation into three major areas: economic globalisation, cultural globalisation, and political globalisation (Babones, 2007). This study considers all aspects of globalisation but focuses on those that facilitate the emergence of Polish, globally oriented elites as consumers of luxury goods including the new forms of elite education. I pay particular attention to the aspects of globalisation theory that underscore the role of transnational corporations (TNCs) in CEE countries.

The initial educational reforms after the 1989 change of the political system were mostly driven by political and social transformation and the introduction of a free market economy. Changes to the market economy in the early 1990 s led to an increasing economic growth rate in following years. Simultaneously, these changes involved various social consequences. The demands of the economic restructurings had an immediate impact on the Polish education system which needed to modernise quickly to suit the demands of the changing economy and to serve the newly mobile and internationally connected parts of the population. At the same time, the strong influx of Foreign Direct Investment (FDI) 2 in the form of TNCs (including transnational education corporations) triggered demand for an internationally minded workforce with cosmopolitan skill sets and knowledge of foreign languages, especially English, leading to the growing attractiveness of international schools and bilingual streams in local schools.

Joining the EU in 2004 and the Schengen border-free zone in March 2008 facilitated further global and European integration, allowing Polish students to visit other countries and to study abroad free as citizens of the EU. 3 The role of prestigious local and international schools has changed. While predominantly serving the needs of transnational corporations and diplomatic corps, they have opened their doors to local, cosmopolitan, globally oriented elites. The growth in numbers of international school operators has been a result of demand and supply driven factors and can be seen as a facet of neoliberal globalisation: the de-nationalisation of education gives private actors an opportunity to step in. Declining state control over education standards and curricula mean that businesses can gain more influence over education.

Beyond pragmatic motives, there has been a growing demand for international schooling among local middle- and upper-class families for the reason of prestige. As researchers have observed, "becoming international (internationalisation), is a strategy for social positioning, a means of upward social mobility: students seek to internationalise their studies, and professionals internationalise their curriculum vitae, careers and social networks" (Basaran \& Olsson, 2017, p. 98). Apart from their traditional clientele of international business families and diplomatic corps,

\footnotetext{
${ }^{2}$ https://www.paih.gov.pl/publications/foreign investors in poland

3 Poland signed the Schengen agreement in December 2, 2007, with the immediate lifting of passport checks for ground and sea border crossings. Airport checks, however, remained until March 29, 2008.
} 
international schools have been increasingly attracting globally oriented Polish local elites who seek prestige and exclusivity.

\subsection{European integration.}

European integration is usually presented as part of globalisation processes and supranational integration driven mainly by economic forces. Indeed, the EU evolved from the European Economic Community to ensure peace and economic growth of its member states. The transnational single market was created to enhance the economic might of the EU and to make the EU economy more competitive. European integration is frequently presented as a result of internationalisation of the economy and increased movement of products and money. With the economic and migration crises occurring recently in Europe, globalisation began to be perceived as a threat rather than an opportunity, leading to a rise in populism and discontent with the EU. Media generally explain the emerging populism in Europe in terms of globalisation destroying local industries and jobs, and redistributing funds in favour of poorer countries. For example, the UK's decision to withdraw from the EU, commonly referred to as 'Brexit', has been frequently explained as a populist reaction to globalisation. Yet, somewhere in this debate about globalisation and the backlash of populism, the foundation goals of the EU are lost. One may argue that blaming globalisation for emerging populism in Europe is a fallacy and that other causes should be taken into consideration.

What began as a predominantly economic union has evolved into an organisation spanning policy areas, from climate, environment and health to external relations and security, justice and migration. Researchers of post-communist transformation often pointed to the 'civilisational' and democratic effects of European integration underscoring the norms of universal human rights, accommodation of racial and multicultural identities and elimination of many forms of discrimination. In the education sphere, an emphasis on universal education, lifelong learning, basic competencies and skills and credit transfers has been applauded by professional and cosmopolitan elites. Some narratives in Poland, however, present European integration as a form of supranational identity transfer that evokes robust resistance among communities whose attachment to national sovereignty and traditions is strongest (Karolewski, 2011; Lane, 2011).

\subsection{The socialist heritage}

The legacies of socialism included historical heritage, institutional practices and sociocultural traits exemplified by political, economic, and cultural-psychological spheres. The positive legacies include factors such as egalitarianism, social welfare, strong community and family networks; however negative legacies also remained, including central control, uniformity, collectivism, mediocrity, political passiveness, and reliance on higher authority, e.g. government or Church, lack of individual initiative, and disengagement in civil society.

Along the obvious remnants of communist tradition, another form of legacy must be brought into focus; a political and cultural process spreading in many CEE societies that demonises socialism and reinforces the hegemony of a neoliberal system. Socialism is perceived as a threat, even by those who would benefit from its redistributive policies. This has been exploited by warring political elites to undermine their opposition and not only to protect economic liberalism and hegemony of TNCs 
but also to resist ecological and human rights policies of the EU and local, nongovernment organisations (NGOs). Social movements such as environmentalism, feminism and progressivism are presented as legacies of the communist era that still features in common national memory as a period of ideological oppression and restriction of individual freedom. As some researchers observed, post-communist CEE societies are more neoliberal than traditional Western economies (Cervinkova \& Rudniski, 2019; Chelcea \& Druţă, 2016). Any attempts to limit the free market or free choice are portrayed as a communist conspiracy agenda.

\subsection{Tradition}

In this study, the angle of tradition includes elements of Poland's socialist heritage but draws, predominantly, on earlier periods of Polish history that have had a major impact on elites' formation, transformation, values and beliefs. I explore how traditionally constituted elites, with strong attachment to national tradition and religion, are far less enthusiastic and even resist globalisation and greater European integration because they see those trends as a threat to national identity and sovereignty.

The critical perspective of tradition helps to problematise Poland's collective values and beliefs, deeply rooted in a strong, patriotic, Catholic tradition. It underscores the differences between cosmopolitan, globally oriented, pro-European elites and those who are more nation-centred and embracing of tradition, particularly the notions of Christianity and Romanticism, and who see the social and cultural (but not necessarily economic) impact of globalisation and EU integration as a threat to national sovereignty and national identity.

Karolewski (2011) contends that the EU attempts to legitimate its own policies by shaping the rules, norms and institutions in third countries and thus promotes the EU as a 'normative power'. The images promoted by the EU are those of 'cosmopolitan Europe, civilian power and normative power' which are confronting to nations with strong cultural and religious national identities (Lane, 2011).

Although Poland has been portrayed by the media and researchers as a pro-global and pro-European country, evidence also points to resistance towards globalisation and noncompliance with EU directives, a phenomenon that some researchers called 'opposition through the back door' (Krause, 2006). Integration into the EU has been touted as the best means by which Poland may develop its industrial and commercial base. However, integration into a supranational entity, governed by a 700-delegate parliament and an extensive administrative apparatus with control and input on national affairs ranging from work pension distributions to nutritional standards, has been greeted with considerable reluctance by many local populations and, occasionally, utilised in political struggles by disunited elites.

\section{The impact of globalisation, European integration, socialist heritage and tradition on the educational reforms.}

The fall of communism in Central and Eastern Europe (CEE) in 1989 marked the beginning of a transition from authoritarian regimes towards capitalist, democratic political systems. Following these systemic changes, the education landscapes of CEE countries needed to rapidly modernise. The initial policy reforms in all post- 
communist CEE countries were driven by the idea of de-constructing and modernising the communist system to suit the requirements of a modern capitalist Western economy (Dudek, 2015; Grabowska \& Szawiel, 2001; Herczyński \& Levitas, 2002; Janowski, 2007; Jakubowski et al., 2010: Wisniewski, 2007). The popular notion of a 'return to Europe', founded on an idealised picture of Western democracy, supported the re-introduction of capitalist modes of production, distribution and consumption. Education policies, similarly, took the direction of decentralisation and democratisation (Klatt \& Elliott, 2016).

The post-communist 'stage one' reforms were mostly driven by changes to the economic system. Market economy adjustments in the early 1990s - 'Balcerowicz shock therapy' (Sachs, 1994) - led to increasing economic growth rate in the following years (Sachs, 1994; Shields, 2004). The demands of the changing economy under economic restructuring had an immediate impact on the Polish education system which needed to modernise quickly. The significant reforms of the deconstruction stage include establishment and growth of non-government educational institutions, including tertiary institutions. The non-government schools were partially or fully selffunded which was a convenient relief for the financially struggling, state education sector.

Simultaneously other social consequences occurred. The most apparent was the scale of unemployment - a phenomenon unknown in the communist Polish People's Republic (PRL) - which increased from less than one percent (1\%) in 1990 to fifteen percent (15\%) in 1995 (GUS, 2019). The model existing during real socialism guaranteeing lifelong employment in state-owned enterprises had broken down (Wisniewski, 2007). Since many young people were trained in work-based schools, drastic reforms were needed to provide inclusive education once these structures were dismantled.

In 1998, the Ministry of National Education published Reforma Systemu EdukacjiProjekt (The Reform of the System of Education-a Proposal, also known as the 'Handke reform') (Ministerstwo Edukacji Narodowej, 1998), that introduced a number of significant reforms reflecting the OECD recommendations. The principal objectives were to raise educational attainment in society by increasing the number of those holding secondary and higher education qualifications, ensuring equal educational opportunities, and supporting improvement of the quality of education. By introducing junior secondary schools called gimnazjum the reform extended a duration of compulsory general education from 8 to 9 years.

According to Klatt and Elliot, the impact of global organisations such as the OECD and the World Bank was noticeable during the early stages of reforms in Poland as in other CEE countries (Klatt \& Elliot, 2016). Tomiak (2000) also notes these external influences alongside internal ones such as the various political parties and Polish educational experts.

Economically driven, the OECD-stimulated reforms were further propelled by another transformational milestone - the accession to the European Union and subsequent adoption of, as well as contribution to, major EU education policies. The notion of a 'return to Europe' dominated the policies of post-communist Central Europe, for the most part reflecting the desire to "leap forward to the achievements of post-war Western Europe" (Snyder, 2003, p. 290). 
The economic and political changes led to the greater opening of Poland and other CEE countries to social and cultural influences from the EU (Alexiadou \& Lange, 2015; MajWasniowska, 2016; Mitter, 2003; Nugent, 2017; Pépin, 2006). The meeting of the Lisbon European Council on 23 and 24 March 2000 was an influential moment. In the conclusions adopted in Lisbon, the Heads of State and Governments agreed on the necessary 'modernisation of the education system'. They aimed to make the EU 'the most competitive and dynamic knowledge economy in the world' by 2010 . The Lisbon Strategy thus brought education from the periphery to the centre and it offered Ministers of Education the opportunity to make themselves heard alongside those responsible for the economy and employment. By taking education on board, the Strategy defined in 2000 marked a turning point in the history of education cooperation at the European level (Pépin, 2011, p. 26). The Lisbon and Nice European Council presidency conclusions (European Council, 2000) were particularly relevant to countries such as Poland that lodged an application to join the EU. They guided the overall 'suitability' to become a part of the European family.

Following the PiS victory in 2015 elections, educational reforms introduced in 2017 known as Reforma Dobra Szkola (The Good School Reform) (Eurofound, 2017; MEN, 2019) phased out the junior secondary schools, shortening the compulsory general education from 9 to 8 years. Gimnazja were a symbol of the successful 1998/99 OECDinspired reforms. Despite criticism from some conservative parents, gimnazja established a strong presence during the Europeanisation stage and were praised by researchers for the successes of Polish students in PISA examinations (Białecki 2017; Klatt \& Elliott, 2016; Zawistowska, 2014).

The PiS reforms aim to modify the curricula with more emphasis on national identitybuilding in subjects such as history, Polish language and literature and religion, clearly under the influence of national tradition (MEN, 2019). The emphasis in some schools on tradition and narrowly understood 'Polish-ness', as opposed to promoting international values and global connections, is becoming a distinguishing attribute between schools and a marketing feature of their educational offer. Although many PiS supporters welcome those changes, critics of the PiS reforms point to the already noticeable shift of students from public to non-public schools (Suchecka, 2018).

PiS reforms of recent years reflect a sharp turning away from globalisation and Europeanisation towards nationalistic modes of operation and centralised government controls (De Lange \& Guerra, 2009). The return of tradition and socialist heritage also marks a growing ideological divide between the Euro-enthusiastic, internationally oriented, cosmopolitan liberal elites and the Euro-sceptic, nation-centric elites who see the processes of globalisation and Europeanisation as threatening Polish national identity (Caiani \& Guerra, 2017; Fomina, 2017).

\section{Typology of Polish elite schools}

The political, economic, social and cultural changes mentioned above, and the educational transformations triggered by them, created conditions that stimulated the emergence of an elite-type education and the elite-type schools that are the object of my study. My study explores different types of elite schools in post-communist Poland as representative of particular elite groups and networks that accompany each type. 
By comparing the similarity and differences of signifiers of elite qualities in the Polish context to those described by studies in the West and Asia, I identify four ideal-typical categories of elite schools. The identified school categories are as follows: international schools - focused on producing international citizens, equipped with cosmopolitan skills and fluent in foreign languages, mainly English; social schools - focused on educating socially conscious citizens, socially and politically involved and committed to democracy; Catholic schools - focused on educating Christian, patriotic Poles, committed to the preservation of national history and tradition, promoting Catholic values and the traditional heteronormative family, and government schools - focused on producing experts and professionals in various fields and promoting competition and meritocracy. These are ideal-typical categories based on the strongest proclivities demonstrated by different groups.

The schools selected for my study are considered elite on the basis of their selectivity and general prestige, high academic results and higher school fees than other schools in their groups. The status of these schools comes from their stratification and networking potential.

\subsection{Elite international schools}

In Poland, the role of schools that are internationally oriented is growing in the rapidly globalising world of multinational businesses, TNCs, global financial organisations and international NGOs. The political and economic changes that followed the 1989 transformation encouraged individual entrepreneurship which led to the emergence of multiple, small and middle-size businesses, at the same time opening the local market to foreign direct investment and the influx of multinational corporations and international businesses, both European and global (Kochan, 2008; Mebrahtu, et al., 2000;). This facilitated movement and exchanges of non-residential economic and social elites, with managers of newly established international enterprises arriving with their families and triggered demand for certifications and education that could be transferred internationally. At the same time, the growing neoliberal economy created local economic elites who became internationally oriented and started looking for schools that offered international certificates and a bilingual curriculum. Some researchers (e.g. Bombol, 2012; Eyal, et al., 1998) point to increasing diversification of Poland's previously classless society, creating new middle and upper classes that are becoming internationally mobile and consumers of luxury goods and services, including elite type education. As degrees cease to promise profitable employment and job markets become highly competitive, many middle- and upper-class parents are becoming more nervous. Consequently, education, particularly high status education, has become a coveted commodity (Ball, 2015; Bunnell, 2014). The strong growth of the middle class and accompanying demand for international education seen in India, China, and the Middle East is also occurring in the new CEE economies, including Poland (Brehm \& Webster, 2014).

The emergence of international schools in Poland is most obviously a result of political and economic globalisation. These schools' aim is to prepare students for further studies at international universities and careers in TNCs and foreign enterprises. They are not interested in Polish tradition or socialist heritage. The attitudes of nationally focused elite parents 4 towards international schooling are suspicious and, sometimes,

\footnotetext{
4 This is shown by my analysis of parents' forums and interviews with principals.
} 
hostile. Reflecting the existing tensions between globally and locally oriented elites, international schools are criticised as promoting values that dilute and diminish the importance of national identity.

\subsection{Elite social schools}

The elite social schools in my study represent a large group of schools, established by influential individuals, parents and teachers, associated with the Social Educational Association (Spoleczne Towarzystwo Oswiatowe or STO). Establishing its first schools in 1989, the STO's goal was to create education institutions independent from the state monopoly, harmoniously combining education and upbringing. The main goals included making schools closer to parents and local communities, perfecting the Polish education system and building a civil society. The STO's mission statement underscores the importance of developing "a sense of civic responsibility for Poland and for Europe and an understanding of the principles of sustainable development" in pupils5.

These schools are born from a desire to create idealised communities of parents, teachers and students based on cooperation and mutual trust. In this environment, parents, teachers, and students "shape the school together, accepting the basic principles and rules such as honesty, reliability, mutual respect and empathy. ... It's about shaping a student as a person: in a mental, social, cultural, and physical sense", says the STO. Beyond this, social schools can have any focus, approach, or orientation. For example, many have extra hours for foreign language studies and sports. As with all independent schools, they may set their own rules for selection of students and the fees they charge. Not all social schools are considered elite. In fact, a majority are not. However, the social schools in my study developed elite reputations by attracting influential social and political individuals and developing powerful networks. Their fees are also higher than average for the schools in this category.

\subsection{Elite Catholic schools}

The third category of elite schools in my study are Catholic schools. After 1989, Catholic schools began to reappear alongside other non-government institutions. Run by religious congregations, dioceses, parishes, as well as private associations and foundations, these schools cater for diverse communities and differ greatly in ranking and degree of prestige. Only some are considered elite. In my study, 'Catholic schools' refers to non-public schools set up by organisations and foundations influenced by Catholic ideology: it does not mean that they are owned or governed by the Catholic Church.

Private Catholic and Christian schools (and any religious-affiliated school), like other schools in Poland, must be sanctioned by the local government. This means they must meet the guidelines established by the Polish Ministry of Education. A few Catholic schools offer the International Baccalaureate (IB) diploma or a bilingual, usually English-Polish programme but, generally, they provide instruction in Polish. The elite

${ }^{5}$ En.sto.org.pl/our-mission 
schools selected for my study are sponsored by private associations influenced by the philosophical and religious ideology of Opus Dei ${ }^{6}$.

\subsection{Elite government schools}

The most prestigious government schools in Poland represent many characteristics of elite schools around the world. They combine a long tradition and historically established prestige ${ }^{7}$ with excellent academic results. The government elite schools in my study are dominating the ranking based on the High School Certificate (Matura) exams. The entrance to these schools is also extremely competitive, based on the final, externally set exams that complete the junior stage of education. Most of these schools cultivate their tradition through their schools' mottos, hymns, commemorative plaques and trophy cabinets. They have strong alumni associations and celebrate the successes of their famous alumni. Graduates of those schools continue education at the best national universities and the most prestigious faculties.

The distinguishing feature of elite government schools is their impressive academic results. They emphasise their power to create winners of Olympiads and various national and international subject competitions. In contrast, non-government, social and international schools advertise that they offer twenty-first century 'soft skills' such as critical thinking and problem-solving skills, creativity and innovation, teamwork and project management, and the opportunity to develop multicultural awareness and connections. Prestigious government schools, with their selectivity, rigorous and demanding academic curriculum and a rather limited range of extracurricular offerings, reflect the communist image of education that was uniform, centralised and based on meritocratic principles.

\section{Conclusion}

This article has presented the major changes to Polish education occurring during the post-communist period from 1989-2018 and linked the forces of globalisation, European integration, socialist heritage and tradition to the major transformational developments. The initial reforms were mainly driven by the demands of economic globalisation and a strong popular reaction against communist legacies. Demands of the changing and expanding economy required the education system to adjust quickly, leading to rapid decentralisation and privatisation. This offered an opportunity for private, legal entities to establish independent educational institutions released from previous ideological biases and with greater flexibility in curriculum delivery and parental participation. Remnants of the centralised and uniform communist education system were complemented and often replaced with new modes of operation more responsive to neoliberal market economy requirements. Decentralisation and privatisation of education created opportunities for new elite schools to emerge and old, pre-World War II elite schools to re-establish and strengthen their status. While elites increasingly seek education in the independent sector, the profile of schools chosen by various elite groups range from those anchored strongly in national tradition, through the socially conscious, civic schools influenced by Europeanisation, to globally-oriented international schools offering a wide range of cosmopolitan and transnational connections. The article invites further research into how elite schools

\footnotetext{
${ }^{6}$ https://oko.press/dworczyk-wychwalal-niestrajkujace-szkoly-swoich-dzieci-to-prywatne-placowki-pod-opiekaopus-dei/

7 All government schools in my study were established in the nineteenth or early twentieth centuries.
} 
contribute to the reproduction of economic and socio-cultural inequalities in Poland and other post-communist countries, and how they contribute to their elites' disunity and tribalism.

\section{References}

Alexiadou, N. \& Lange, B (2015) Europeanizing the national education space? Adjusting to the Open Method of Coordination (OMC) in the UK, InternationalJournal of Public Administration, 38:3, 157-166.

Babones, S. (2007). Studying globalization: Methodological issues. The Blackwell companion to globalization, 144-161. Blackwell.

Ball, S. (2015) Elites, education and identity: An emerging research agenda. In van Zanten, A, Ball, S., Darchy-Koechlin, B. (Eds.) Elites, privilege and excellence: The national and global redefinition of educational advantage. Taylor and Francis.

Basaran, T., \& Olsson, C. (2018). Becoming international: On symbolic capital, conversion and privilege. Millennium, 46(2), 96-118.

Białecki, I., Jakubowski, M., \& Wiśniewski, J. (2017). Education policy in Poland: The impact of PISA (and other international studies). European Journal of Education, 52(2), 167-174.

Bombol, M. (2012). Ksztattująca się polska klasa wyższa: szkice ekonomiczno-społeczne. Szkoła Głóna Handlowa-Oficyna Wydawnicza.

Bowman, N. A., \& Bastedo, M. N. (2009). Getting on the front page: Organizational reputation, status signals, and the impact of US News and World Report on student decisions. Research in Higher Education, 50(5), 415-436.

Brehm, W.C. \& Webster, O. C. (2014) Global, European or local citizenship?: The discursive politics of citizenship education in Central and Eastern Europe. Globalizing Minds: Rhetoric and realities in international schools, Information Age Publishing, pp. 225-248.

Bunnell, T. (2014). The changing landscape of international schooling: Implications for theory and practice. Taylor and Francis.

Caiani, M., \& Guerra, S. (Eds.). (2017). Euroscepticism, democracy and the media: Communicating Europe, contesting Europe. Springer.

Cervinkova, H., \& Rudnicki, P. (2019). Neoliberalism, neoconservatism, authoritarianism. The politics of public education in Poland. Journal for Critical Education Policy Studies (JCEPS), 17(2).

Chelcea, L., \& Druţă, O. (2016). Zombie socialism and the rise of neoliberalism in postsocialist Central and Eastern Europe. Eurasian Geography and Economics, 57(4-5), 521-544.

De Lange, S. L., \& Guerra, S. (2009). The league of Polish families between East and West, past and present. Communist and Post-Communist Studies, 42(4), 527-549.

Dudek, A. (2015). The consequence of the system transformation of 1989 in Poland. Remembrance and Solidarity Studies. Issue 3. ENRS. http://www.enrs.eu/en/articles/1516-the-consequence-of-the-systemtransformation-of-1989-in-poland 
Eurofound (2017). Poland. Government enacts radical education reform despite opposition. Retrieved from:

https://www.eurofound.europa.eu/observatories/eurwork/articles/polandgovernment-enacts-radical-education-reform-despite-opposition

European Commission/EACEA/Eurydice, (2012). Developing key competences at school in Europe: Challenges and opportunities for policy. Eurydice Report. Publications Office of the European Union.

European Council (2000). Presidency conclusions: European Council, Lisbon, 23 and 24 March 200o. European Council.

Eyal, G., Szelényi, I., Szelényi, I., \& Townsley, E. R. (1998). Making capitalism without capitalists: Class formation and elite struggles in post-communist Central Europe. Verso.

Fomina, J. (2017). The unlikely Eurosceptics: The undercurrent anti-European attitudes among young Poles and the role of the domestic context. Polish Sociological Review, 2, 198.

Gatzambide-Fernández, Rubèn A. (2009). The best of the best: Becoming elite at an American boarding school. Harvard University Press.

Grabowska, M., \& Szawiel, T. (2001). Budowanie demokracji: Podziały społeczne, partie polityczne i spoleczenstwo obywatelskie $w$ postkomunistycznej Polsce. Wydawnictwo Naukowe PWN.

GUS Glowny Urzad Statystyczny, (2019). Oświata i wychowanie w roku szkolnym 2018/2019 Education in the 2018/2019 school year. Retrieved from: https://stat.gov.pl/en/topics/education/education/education-in-the-20182019school-year,1,15.html

Herczyński, J., \& Levitas, T. (2002). Decentralization, local governments and education reform in post-communist Poland. Balancing national and local responsibilities. Education management and finance in four Central European Countries. Local Government and Public Service Reform Initiative-Open Society Institute.

Jakubowski,M., Patrinos,H. A., Porta, E. E.,Wisniewski,J. (2010), The impact of the 1999 education reform, Policy Research Working Paper 5263. The World Bank Human Development Network, Education Team, April 2010.

Janowski, A. (2007). Educational restructuring and change: Post-communist educational transformation in Poland. Orbis Scholae, 1(2), 80-109.

Karolewski, I. P. (2011). European identity making and identity transfer. In D. Lane (Ed.), Elites and identities in post-Soviet space (pp. 21-42). Routledge.

Kenway, J., \& Koh, A. (2015). Sociological silhouettes of elite schooling. British Journal of Sociology of Education, 36(1), 1-10

Klatt, M. (2013). European Union integration and its influence on the education reforms in Central-Eastern Europe-the case of Poland. Yearbook of the Institute of East-Central Europe. 2(6) 117-131.

Klatt, M., \& Elliott, K. (2016). Education reforms in Central Eastern Europe and its impact on youth transitions - a case of Poland. In S. Bohlinger, K. Dang, \& M. Klatt (Eds.), Education Policy: mapping the landscape and scope, pp. 353-376. Peter Lang AG. 
Kochan, A. B. (2008). The borderless school: Globalization of Polish education. Political Crossroads, 15(2), 77-111.

Krause, K. (2006). European Union directives and Poland: A case study. U. Pa. J. Int'l Econ. L., 27, 155 .

Lane, D. (2011). Identity formation and political elites in the post-socialist states. EuropeAsia Studies, 63(6), 925-934.

Maj-Waśniowska, K. (2016). Wpływ polityki Unii Europejskiej na kierunki zmian w polskim systemie edukacji. Finanse, Rynki Finansowe, Ubezpieczenia, 6 (84) Cz. 2 Planowanie wieloletnie-efektywność zadań publicznych-benchmarking), 151-168.

Mebrahtu, T., Crossley, M., \& Johnson, D. (Eds.). (2000). Globalisation, educational transformation and societies in transition. Symposium Books Ltd.

MEN Ministerstwo Edukacji Narodowej (2019). Reforma Edukacji https://www.gov.pl/web/edukacja/reforma-edukacji

MEN Ministerstwo Edukacji Narodowej (August 2005), Strategia Rozwoju Edukacji na lata 2007-2013. Ministry of National Education in Poland.

MEN Ministerstwo Edukacji Narodowej (1998). Reforma systemu edukacji (projekt). Wydawnictwa Szkolne i.

Mitter, W. (2003). A decade of transformation: Educational policies in Central and Eastern Europe. International Review of Education, 49(1-2), 75-96.

Nugent, N. (2017). The government and politics of the European Union. Palgrave.

OECD. (1995). Literacy, economy and society. Results of the first International Adult Literacy Survey. OECD and Statistics Canada.

Pépin, L. (2006). The history of European cooperation in education and training: Europe in the making, an example. Office for Official Publications of European Communities.

Pépin, L. (2011). Education in the Lisbon Strategy: assessment and prospects. European Journal of Education, 46(1), 25-35.

Sachs, J. (1994). Shock therapy in Poland: Perspectives of five years. The Tanner Lectures on Human Values. https://tannerlectures.utah.edu/ documents/a-toz/s/sachs95.pdf

Shields, S. (2004) Global restructuring and the Polish state: transition, transformation, or transnationalisation? Review of International Political Economy. 11(1), 132154 .

Snyder, T. (2003) The reconstruction of nations: Poland Ukraine, Lithuania, Belarus, 15691999. Yale University Press.

Suchecka, J. (2018) Ucieczka od reformy edukacji. Gazeta Wyborcza, (13.04). retrieved from http://wyborcza.pl/7,75398,23263829, ucieczka-od-reformy-edukacji-rodzicezabieraja-dzieci-z-przepelnionych.html [accessed: 23.04.2018]

Tomiak, J. J. (2000). Polish education facing the twenty-first century: Dilemmas and difficulties. Comparative Education, 36(2), 177-186.

Vidaver-Cohen, D. (2007). Reputation beyond the rankings: A conceptual framework for business school research. Corporate Reputation Review, 10(4), 278-304. 
Wisniewski, J. (2007). Secondary education in Poland: 18 years of changes. Fourth ECA Education.

Zawistowska, A. (2014). The Black Box of the educational reforms in Poland: What caused the improvement in the PISA scores of Polish atudents?. Polish Sociological Review, 187(3), 333-350. 